\title{
Economic Activity of the Population by Age in the European Union Countries
}

\author{
Ewa Pośpiech* and Adrianna Mastalerz-Kodzis
}

Department of Statistics, Econometrics and Mathematics, University of Economics in Katowice, Poland

\begin{tabular}{|c|c|}
\hline ARTICLE INFO & ABSTRACT \\
\hline $\begin{array}{l}\text { Keywords: } \\
\text { Employment rate } \\
\text { Employment structure } \\
\text { by age } \\
\text { Labour market in the } \\
\text { EU countries } \\
\text { Quantitative research } \\
\text { on the labour market } \\
\text { characteristics } \\
\text { Spatial analysis of } \\
\text { employment }\end{array}$ & $\begin{array}{l}\text { The employment level research is an important element of economic } \\
\text { analyses supporting the conduct of efficient regional or country policy. } \\
\text { Many factors influence the level of this phenomenon, these are } \\
\text { demographic, social and economic factors. The employment level can } \\
\text { be considered in various categories and the demographic changes } \\
\text { encourage to carry out employment analyses by age. Therefore, the } \\
\text { subject of the analysis was employment (employment rate) of the } \\
\text { European Union countries broken down by age. The main purpose of the } \\
\text { article was to show similarities and differences in the level and structure } \\
\text { of employment occurring in the European Union countries, and besides, } \\
\text { examining the existence of spatial patterns in the period under } \\
\text { investigation. To achieve this goal, selected quantitative tools were used, } \\
\text { including classic and positional measures of central tendency, indicators } \\
\text { of dynamics (average change rate) and measures of interdependence } \\
\text { between variables (Pearson's correlation coefficient). In addition, } \\
\text { selected spatial autocorrelation measures (global and local Moran's } \\
\text { statistic) were used to identify spatial dependences. Data for analyses } \\
\text { were taken from the Eurostat database. The results of the research } \\
\text { showed the changing employment structure (by age) in the European } \\
\text { Union countries and showed the existence of certain spatial } \\
\text { dependences, especially in the oldest group of employed persons. }\end{array}$ \\
\hline
\end{tabular}

\section{Introduction}

Employment is a complex issue, and its specificity is associated with many factors, which include demographic, social and economic conditions (Marciniak, 2013). It is an important element of any regional and national policy. Its characteristics and determinants are important information for authorities at various levels. Monitoring this phenomenon and managing it appropriately gives the opportunity to control it and improves, among others, the process of implementing the appropriate socio-economic policy of a given region or country.

The problem of employment can be considered, e.g. by sex, place of residence, level of education, type of activity, age, etc. The last of these criteria allows the analysis of the level of employment in different age categories. This is especially important now when we observe demographic changes (e.g. aging of societies (Jóźwiak, 2013; Mastalerz-Kodzis et al., 2017)). That is why the article analyses the employment level in the European Union countries, taking into account the division into age groups. An analysis of the dynamics and structure of employment in these countries was conducted, as well as the correlation between the employment rate and GDP (PPS per capita) was examined. Many phenomena associated with a specific location are correlated not only with other socio-economic characteristics, but also with this location (Tobler, 1970). These include demographic processes, phenomena occurring

* Corresponding Author E-Mail Address: posp@ue.katowice.pl 
on the real estate market, living standards of the population, economic development in a given area, etc. (Overmars et al., 2003; Pietrzykowski, 2011; Pośpiech, 2015; Pośpiech \& MastalerzKodzis, 2015; Zeug-Żebro, 2014). The employment level was also analyzed for the presence of a spatial factor. Therefore, in order to identify spatial dependences, the spatial autocorrelation analysis of the discussed issue was conducted.

The aim of the article is above all to show similarities and differences in the level and structure of employment occurring in the European Union countries, taking into account the division into age groups, as well as to investigate the existence of spatial dependences within the considered phenomenon.

\section{Methodology of the empirical analysis}

The analysis of the studied issue was carried out using selected quantitative tools. Descriptive statistics tools (classic and positional measures of central tendency, dynamic indicators, and measures of interdependence of phenomena) were used, as well as selected tools of spatial statistics and econometrics, such as global and local Moran's statistics, which enable the study of the presence of spatial autocorrelation. The global Moran's statistic is calculated according to the following formula (Cliff \& Ord, 1973; Kopczewska, 2011; Suchecki, 2010):

$$
I=\frac{1}{\sum_{i=1}^{n} \sum_{j=1}^{n} w_{i j}} \cdot \frac{\sum_{i=1}^{n} \sum_{j=1}^{n} w_{i j}\left(x_{i}-\bar{x}\right)\left(x_{j}-\bar{x}\right)}{\frac{1}{n} \sum_{i=1}^{n}\left(x_{i}-\bar{x}\right)^{2}}=\frac{n}{S_{0}} \cdot \frac{\mathbf{z}^{\mathbf{T}} \mathbf{W} \mathbf{z}}{\mathbf{z}^{\mathbf{T}} \mathbf{z}},
$$

Where: $x_{i}, x_{j}-$ observations in studied regions,

$\bar{x}$ - The arithmetic mean (for all regions and observations),

$n-$ the number of included regions,

$\mathbf{z}$ - the column vector of the following values: $z_{i}=x_{i}-\bar{x}, i=1, \ldots, n$,

$S_{0}$ - the sum-total of weights matrix elements, $S_{0}=\sum_{i=1}^{n} \sum_{j=1}^{n} w_{i j}$,

W - the weights matrix $w_{i j}, i=1, \ldots n, j=1, \ldots, n$, consisting of the following elements:

$$
w_{i j}= \begin{cases}1, & \text { when objects } i \text { and } j \text { share a border } \\ 0, & \text { when objects } i \text { and } j \text { do not share a border } \\ 0, & \text { for diagonal elements }\end{cases}
$$

The following hypotheses are formulated $-\mathrm{H}_{0}$ : absence of spatial autocorrelation (the values of a given variable are randomly distributed), $\mathrm{H}_{1}$ : presence of spatial autocorrelation (positive or negative). The hypotheses are tested using the following test statistic:

$$
Z_{I}=\frac{I-\mathrm{E}(I)}{\sqrt{\operatorname{Var}(I)}}
$$

Where $Z_{I} \sim \mathrm{N}(0,1), \mathrm{E}(I)$ and $\operatorname{Var}(I)$ are specified as follows:

$$
\begin{gathered}
\mathrm{E}(I)=-\frac{1}{n-1}, \\
\operatorname{Var}(I)=\frac{n\left[\left(n^{2}-3 n+3\right) S_{1}-n S_{2}+3 S_{0}^{2}\right]-k\left[\left(n^{2}-n\right) S_{1}-2 n S_{2}+6 S_{0}^{2}\right]}{(n-1)(n-2)(n-3) S_{0}^{2}}-\frac{1}{(n-1)^{2}}, \\
S_{0}=\sum_{i=1}^{n} \sum_{j=1}^{n} w_{i j}, S_{1}=\frac{1}{2} \sum_{i=1}^{n} \sum_{j=1}^{n}\left(w_{i j}+w_{j i}\right)^{2}, S_{2}=\sum_{i=1}^{n}\left(\sum_{j=1}^{n} w_{i j}+\sum_{j=1}^{n} w_{j i}\right)^{2},
\end{gathered}
$$




$$
k=\frac{\frac{1}{n} \sum_{i=1}^{n}\left(x_{i}-\bar{x}\right)^{4}}{\left[\frac{1}{n} \sum_{i=1}^{n}\left(x_{i}-\bar{x}\right)^{2}\right]^{2}} .
$$

Positive autocorrelation indicates that similar values tend to cluster together at a certain location, while negative autocorrelation means that high and low values are adjacent (chessboard structure) - the higher the absolute value of the statistic, the stronger the spatial patterns. In the case of no spatial autocorrelation we say about random distribution of the variable values.

The local Moran's $I_{i}$ statistic allows identifying clusters of high and low values of the examined characteristic, as well as indicating outliers. It is computed according to the formula:

$$
I_{i}=\frac{\left(x_{i}-\bar{x}\right) \sum_{j=1}^{n} w_{i j}^{*}\left(x_{j}-\bar{x}\right)}{\sum_{i=1}^{n}\left(x_{i}-\bar{x}\right)^{2}},
$$

where: $w_{i j}^{*}$ - elements of the weight's matrix, calculated as follows $w_{i j}^{*}=\frac{w_{i j}}{\sum_{j=1}^{n} w_{i j}}$,

and other symbols as in the above.

Assuming the statistic $Z_{I_{i}}$ expressed by the formula (Anselin, 1995):

$$
Z_{I_{i}}=\frac{I_{i}-\mathrm{E}\left(I_{i}\right)}{\sqrt{\operatorname{Var}\left(I_{i}\right)}},
$$

where:

$$
\mathrm{E}\left(I_{i}\right)=-\frac{\sum_{j=1}^{n} w_{i j}}{n-1}, \operatorname{Var}\left(I_{i}\right)=\frac{(n-k) \sum_{j \neq i} w_{i j}^{2}}{n-1}+\frac{2(2 k-n) \sum_{k \neq i} \sum_{l \neq i} w_{i k} w_{i l}}{(n-1)(n-2)}-\frac{\left(\sum_{j=1}^{n} w_{i j}\right)^{2}}{(n-1)^{2}},
$$

has an asymptotic normal distribution, we can decide (at a given significance level) to accept or reject the null hypothesis that there is no clustering of large or small values of a variable in the neighbourhood of the $i$ area.

Interpretation of the values of the statistic $I_{i}$ is as follows: a positive statistically significant value of the statistic indicates that the region $i$ is surrounded by areas where the considered characteristic takes similar values (i.e. similar values are clustered), while a negative statistically significant value of the statistic means that the region $i$ is surrounded by areas where the characteristic has different values (outlier).

\section{Results of empirical analysis}

The subject of the analysis was the level of employment in the European Union countries broken down into different age categories. This phenomenon was studied in dynamic, structural and spatial terms.

As the period of economic activity of the population, the age range from 15 to 64 is most often adopted, however in these studies as a group of professionally active people (employed persons) was considered a group of people aged 15 and over. Depending on the type of analysis, 10 -year intervals were taken into account or the groups of the youngest (15-24), people aged 25-54 and the group of the oldest (55 years or over) were analyzed. Including such a division resulted from the structure of employees. The period covered by the analysis is 2002-2018. 


\subsection{Analysis of the dynamics of the number of employed persons}

The first part of the considerations included the study of the dynamics of changes in the number of employed persons in individual age groups. It was tested using the average rate of change. The obtained results are presented in Tab. 1.

Table 1.

Average annual rate of change of the number of employed persons (\%)

\begin{tabular}{|c|c|c|c|c|c|c|c|c|c|}
\hline \multirow[b]{2}{*}{ Countries } & \multicolumn{9}{|c|}{ Age range } \\
\hline & $\begin{array}{l}15 \text { years } \\
\text { or over }\end{array}$ & $15-64$ & $25-54$ & $15-24$ & $25-34$ & $35-44$ & $45-54$ & $55-64$ & $\begin{array}{l}65 \text { years } \\
\text { or over }\end{array}$ \\
\hline EU -28 countries & 0.7 & 0.6 & 0.2 & -1.0 & -0.5 & -0.3 & 1.2 & 4.2 & 3.4 \\
\hline Belgium (BE) & 1.0 & 1.0 & 0.4 & -0.6 & 0.1 & -0.5 & 1.5 & 6.4 & 6.3 \\
\hline Bulgaria (BG) & 0.7 & 0.7 & 0.2 & -3.4 & -0.2 & -0.1 & 0.2 & 4.9 & 4.7 \\
\hline Czechia (CZ) & 0.7 & 0.6 & 0.5 & -3.2 & -0.6 & 1.6 & 0.1 & 3.6 & 6.3 \\
\hline Denmark (DK) & 0.3 & 0.2 & -0.3 & 0.8 & -0.6 & -0.8 & 0.5 & 2.0 & 4.5 \\
\hline Germany (DE) & 0.9 & 0.8 & 0.1 & -0.2 & 0.4 & -1.8 & 1.5 & 4.6 & 7.4 \\
\hline Estonia (EE) & 0.8 & 0.6 & 0.2 & 0.3 & 0.2 & -0.5 & 0.3 & 2.8 & 4.6 \\
\hline Ireland (IE) & 1.6 & 1.5 & 1.5 & -1.0 & 0.0 & 2.0 & 2.4 & 4.1 & 4.9 \\
\hline Greece (GR) & -0.7 & -0.7 & -0.6 & -5.9 & -2.6 & 0.0 & 1.0 & 1.1 & -0.9 \\
\hline Spain (ES) & 0.9 & 0.9 & 0.9 & -4.1 & -1.9 & 0.9 & 3.1 & 4.1 & 3.9 \\
\hline France (FR) & 0.8 & 0.7 & 0.1 & 0.2 & -0.2 & -0.2 & 0.8 & 5.2 & 8.6 \\
\hline Croatia (HR) & 0.5 & 0.6 & 0.2 & -1.3 & 0.5 & -0.3 & -0.2 & 5.5 & -4.0 \\
\hline Italy (IT) & 0.4 & 0.3 & -0.2 & -2.8 & -2.4 & -0.4 & 2.0 & 5.1 & 3.9 \\
\hline Cyprus (CY) & 1.5 & 1.5 & 1.3 & -0.3 & 1.7 & 0.7 & 1.3 & 4.1 & 1.6 \\
\hline Latvia (LV) & -0.3 & -0.4 & -0.7 & -3.1 & -0.8 & -1.8 & -0.2 & 2.7 & 2.1 \\
\hline Lithuania (LT) & -0.2 & -0.3 & -1.0 & -1.5 & -1.1 & -2.7 & 0.6 & 3.7 & 4.5 \\
\hline Luxembourg (LU) & 2.5 & 2.5 & 2.3 & 1.3 & 1.8 & 1.3 & 3.6 & 5.6 & 4.9 \\
\hline Hungary (HU) & 0.9 & 0.9 & 0.5 & -1.8 & -0.9 & 1.1 & 0.5 & 5.8 & 6.8 \\
\hline Malta (MT) & 3.0 & 2.9 & 3.3 & -0.7 & 4.3 & 1.5 & 1.6 & 5.9 & 8.6 \\
\hline Netherlands (NL) & 0.5 & 0.3 & -0.4 & 0.0 & -0.6 & -1.5 & 0.7 & 5.1 & 7.1 \\
\hline Austria (AT) & 1.0 & 1.0 & 0.4 & 0.1 & 0.1 & -0.9 & 2.2 & 5.9 & 5.5 \\
\hline Poland (PL) & 1.1 & 1.1 & 0.6 & -0.9 & 0.7 & 0.2 & 0.0 & 6.6 & 0.7 \\
\hline Portugal (PT) & -0.4 & -0.3 & -0.3 & -4.2 & -2.2 & -0.1 & 1.1 & 2.2 & -1.7 \\
\hline Romania (RO) & -0.7 & -0.4 & -0.4 & -4.1 & -2.5 & 0.5 & 0.5 & 1.9 & -5.8 \\
\hline Slovenia (SI) & 0.4 & 0.4 & 0.0 & -1.6 & -1.0 & 0.1 & 0.7 & 5.8 & -1.1 \\
\hline Slovakia (SK) & 1.2 & 1.2 & 0.7 & -2.4 & 0.5 & 0.7 & 0.5 & 8.6 & 12.3 \\
\hline Finland (FI) & 0.3 & 0.2 & -0.3 & -0.4 & 0.4 & -0.5 & -0.7 & 3.1 & 9.7 \\
\hline Sweden (SE) & 1.0 & 0.9 & 0.8 & 0.8 & 1.2 & 0.2 & 1.0 & 1.2 & 5.9 \\
\hline United Kingdom (GB) & 1.0 & 0.8 & 0.7 & -0.2 & 0.8 & -0.5 & 1.5 & 2.6 & 6.2 \\
\hline
\end{tabular}

Source: Own calculations based on data from the Eurostat database

Comparing the average rate of change in groups 15-64 and 15 or over, we notice very similar values. An analysis of the index value for the age group of 15 or over allows us to conclude that on average from year to year Malta (3\%), Luxembourg (2.5\%), Ireland (1.6\%), Cyprus $(1.5 \%)$, Slovakia $(1.2 \%)$ and Poland $(1.1 \%)$ had the highest growth dynamics, while the average annual rate of decline in the number of employees was recorded in Greece and Romania (-0.7\%), Portugal (-0.4\%), Latvia (-0.3\%) and Lithuania (-0.2\%). The highest average annual decreases are visible in the youngest group (15-24) - the largest of them were recorded by Greece $(-5.9 \%)$, Portugal $(-4.2 \%)$ as well as Spain and Romania (-4.1\%). The average annual growth in this age category is observed only in a few countries; the highest average growth rate was recorded in Luxembourg (1.3\%), Denmark and Sweden (0.8\%). In the group 
of people aged 25-34, fourteen countries recorded an average decrease from year to year, thirteen - an increase, and in one (Ireland) there were no changes. The highest average increase from year to year was recorded in Malta (4.3\%), Luxembourg (1.8\%) and Sweden (1.2\%), while the largest decrease in the rate of change was visible in Greece (-2.6\%), Romania ($2.5 \%)$, Italy $(-2.4 \%)$ and Portugal (-2.2\%). In the next age category (35-44) the largest decrease in the average rate of change in 2002-2018 was observed in Lithuania (-2.7\%), Latvia and Germany (-1.8\%), while the highest average growth rate of the number of employees was recorded in Ireland (2\%). In the group of people aged 45 to 54, only in three countries the average annual rate of change was negative: in Finland (-0.7\%), Croatia and Latvia $(-0.2 \%)$. Increases were observed in other countries, with the largest being recorded in Luxembourg (3.6\%), Spain (3.1\%), Ireland (2.4\%), Austria (2.2\%) and Italy (2\%). In the penultimate examined category (55-64), increases in the average annual rate of change were observed in each EU country. The highest were recorded in Slovakia (8.6\%), Poland (6.6\%) and Belgium $(6.4 \%)$, while the lowest were in Greece (1.1\%), Sweden (1.2\%) and Romania (1.9\%). The growth rate for the entire Union was $4.2 \%$. Among the oldest, over 65, the average annual rate of change in the number of employees was negative in five countries: Romania (-5.8), Croatia $(-4 \%)$, Portugal $(-1.7 \%)$, Slovenia $(-1.1 \%)$ and Greece $(-0.9 \%)$. The highest growth rates were recorded in Slovakia (12.3\%), Finland (9.7\%), Malta and France (8.6\%). The EU average in this age category was $3.4 \%$.

The analysis of the results obtained above all shows a decrease or slight increase in the number of employees in the youngest age categories and a significant average increase in the number of employees in the categories of the oldest. At least a few factors that shape this phenomenon can be indicated here. The observed increasing economic activity among the elderly can have a dual basis - on the one hand, people want to pursue their profession as long as possible, on the other, they are forced to take a job due to insufficient retirement benefits that do not ensure basic existence. The reason for this is also the longer life expectancy. In turn, one of the undoubted reasons for the downward trend in the average rate of change in the number of employed among the youngest (despite the phenomenon of taking up work, e.g. during studies) are demographic changes observed in European countries - constantly low birth rates, and a changing age structure of the population (less people young, increasing number of older people (Eurostat, July 2019)).

\subsection{Analysis of the employment rate}

The next part of the study analyzes the employment rate for individual age groups understood as the share of persons working in a given category in the total population of a given group. The analysis of dynamics showed the most interesting results in the group of youngest and oldest people, therefore in this part of the study the focus was mainly on these groups.

Tab. 2 shows the boundaries of the ranges, which were taken into account when dividing the values for individual age groups - minimum, maximum and quartiles values were determined, which allowed to separate four groups within each category.

Table 2.

Values of selected characteristics

\begin{tabular}{lllll}
\hline \multirow{2}{*}{ Characteristics } & \multicolumn{3}{l}{ Age groups } & \\
\cline { 2 - 5 } & 15 or over & $15-24$ & $55-64$ & 64 or over \\
\hline MIN & 37.7 & 11.8 & 21.1 & 0.5 \\
Q1 & 49.2 & 24.6 & 38.5 & 2.9 \\
Me & 53.0 & 29.0 & 46.4 & 4.9 \\
Q3 & 57.2 & 43.4 & 55.4 & 7.4 \\
MAX & 63.7 & 70.5 & 77.9 & 25.7 \\
\hline
\end{tabular}

Source: Own calculations based on data from the Eurostat database 
Fig. 1, 2, 3 and 4 show how the employment rate levels developed for selected age groups and selected years $(2002,2010,2018)$ - the darker the colour, the higher the employment rate.

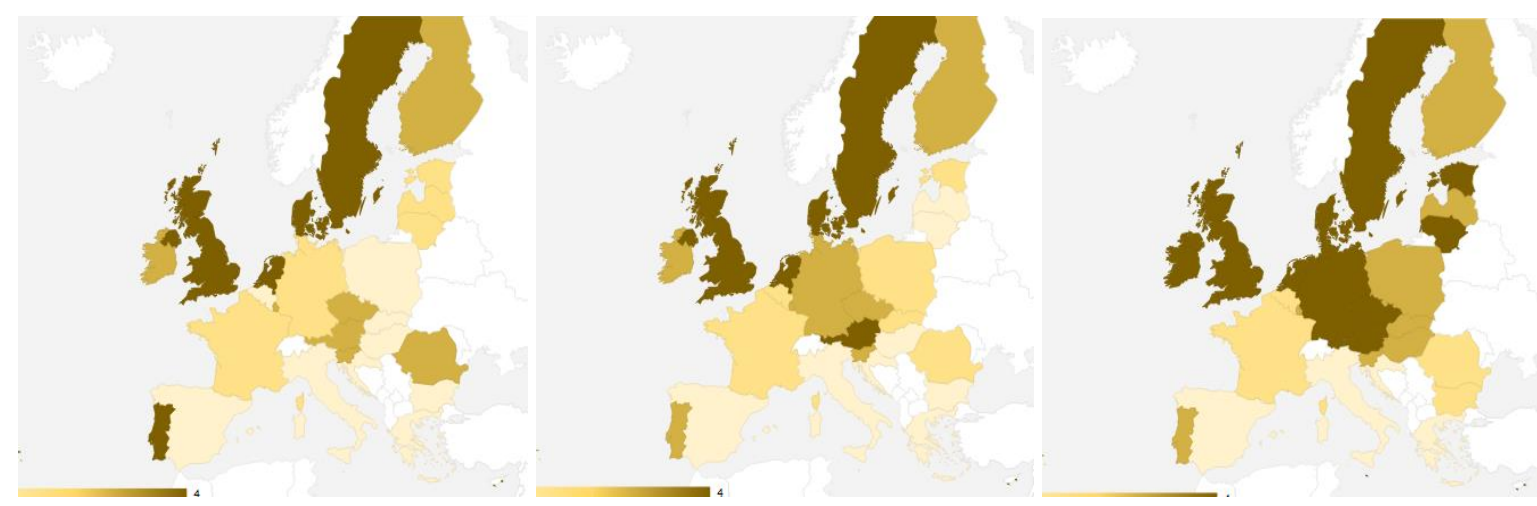

Figure 1. Employment rate in 2002, 2010 and 2018 respectively, in the group aged 15 or more (Source: Own study based on data from the Eurostat database)

Fig. 1 shows how the employment rate has changed over the years 2002-2018 in the category of employed persons over 15 years of age. The largest changes (increases) are noticeable in the levels of the studied indicator in Central-Western Europe and the countries of the so-called the "new" Union. Over the years under review, the employment rate level has risen in everywhere in almost all countries. A significantly lower level of employment rate (by 4 percentage points) was recorded in Portugal.

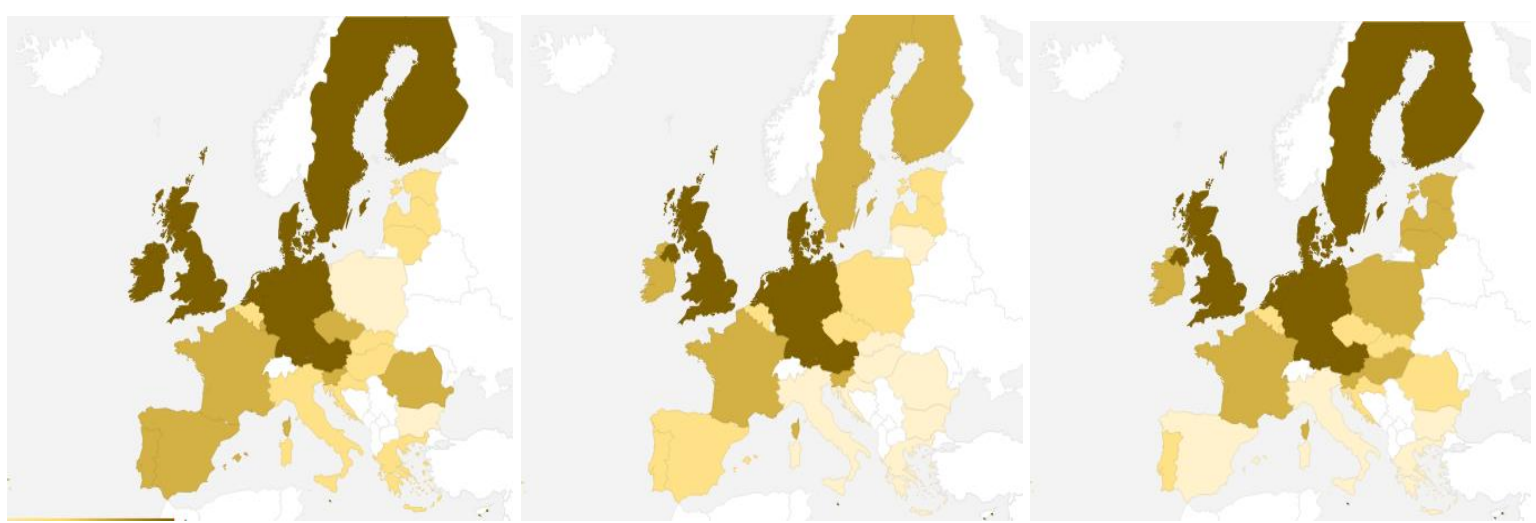

Figure 2. Employment rate in 2002, 2010 and 2018 respectively, in the group aged 15-24 (Source: Own study based on data from the Eurostat database)

Dynamic changes in the levels of the examined indicator are noticeable in the group of the youngest working people (Fig. 2). The structure in selected years changed most in Southern Europe as well as Central and Eastern Europe and Scandinavia. Lower levels of the phenomenon (except for a few countries) were recorded in 2010, which followed the peak of the global crisis. Essential changes are visible for Spain and Poland. In Spain, the employment rate significantly decreased (from $34.3 \%$ to $21.7 \%$ ) over the period considered, while the opposite was true in Poland - the rate increased from $22 \%$ to $31 \%$. Countries with employment rates above quartile Q3 (43.4\%) include Denmark, Germany, Malta, the Netherlands, Austria, Finland and Sweden (except 2010) and the United Kingdom. In these countries, the employment rate of very young people is the highest among EU countries. 


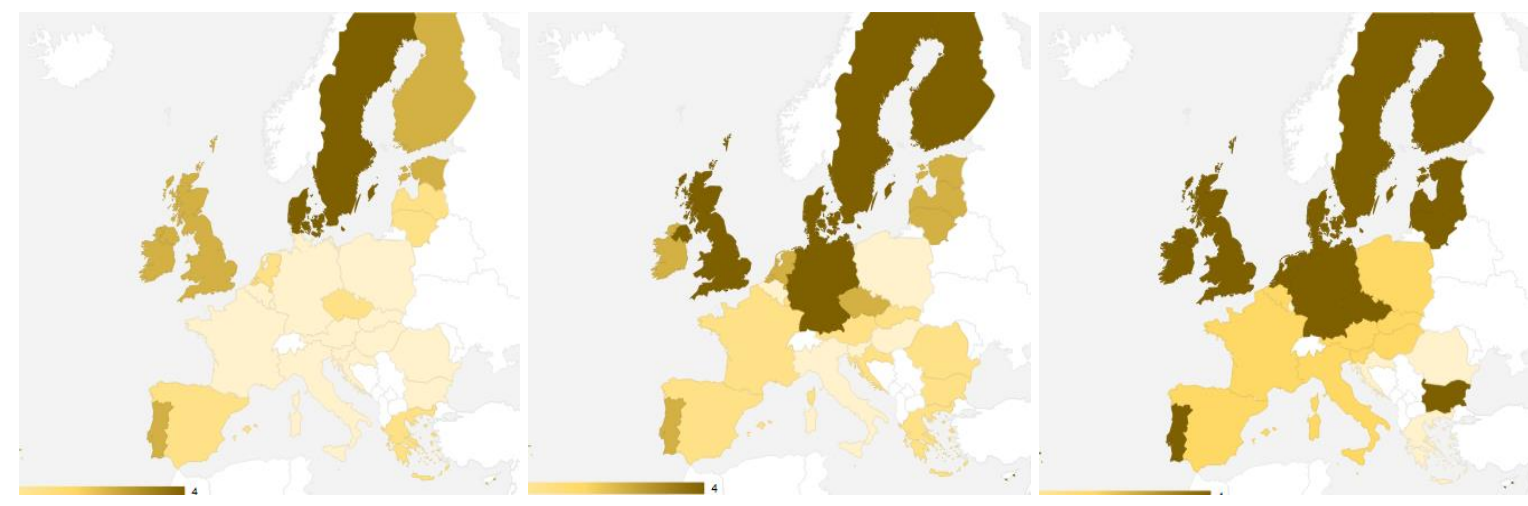

Figure 3. Employment rate in 2002, 2010 and 2018 respectively, in the group aged 55-64 (Source: Own study based on data from the Eurostat database)

In the category of older people (55-64) there is a visible tendency for the employment rate to increase in all the countries studied (Fig. 3). This confirms previous conclusions resulting from the dynamics analysis. This group of employees recorded the largest change in employment levels over the period under review.

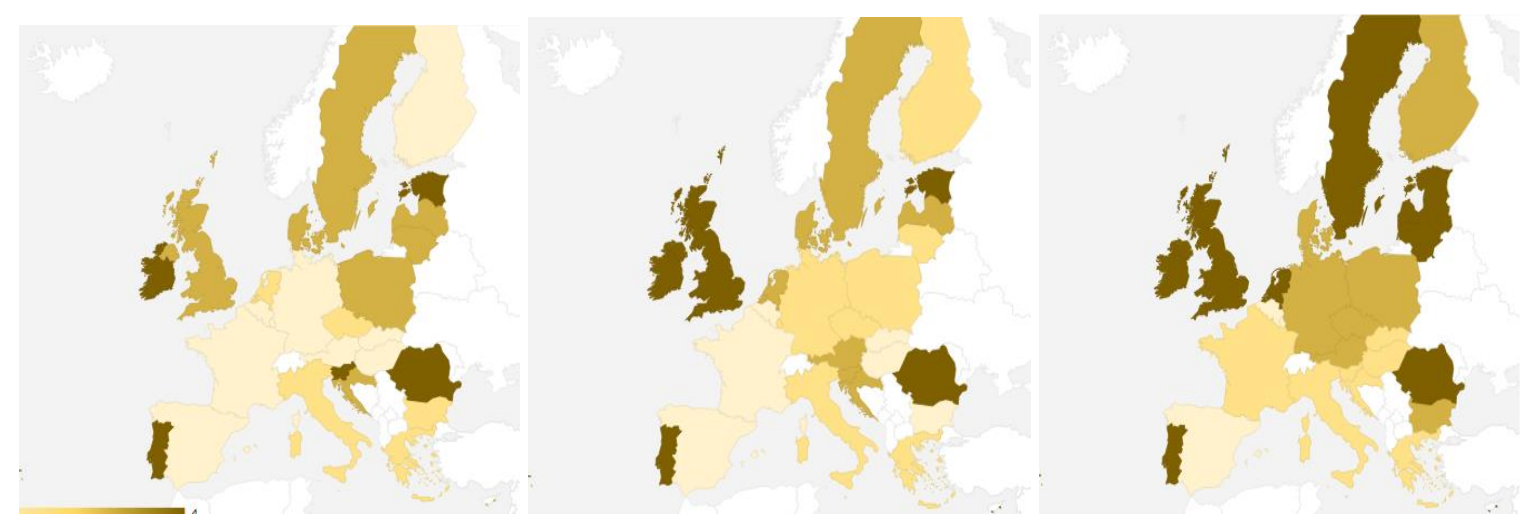

Figure 4. Employment rate in 2002, 2010 and 2018 respectively, in the group aged 65 or more (Source: Own study based on data from the Eurostat database)

In the group of the oldest working people, increasing employment rate tendencies are mainly visible, especially when comparing the distribution of the indicator value in 2018 to 2002 (Fig. 4) - for many countries, this increase is significant (e.g. Finland or the United Kingdom). However, in a few countries a downward trend is noted. The examples of the decreasing value of the employment rate over the years are Greece, Croatia, Portugal and Romania (this is not directly visible in Fig. 4, but it results from the analysis of the employment rate values for these countries).

The supplementation to the presented considerations is to show the employment structure of all countries in the years 2002 and 2018. Fig. 5 shows the employment structure in 2002. 


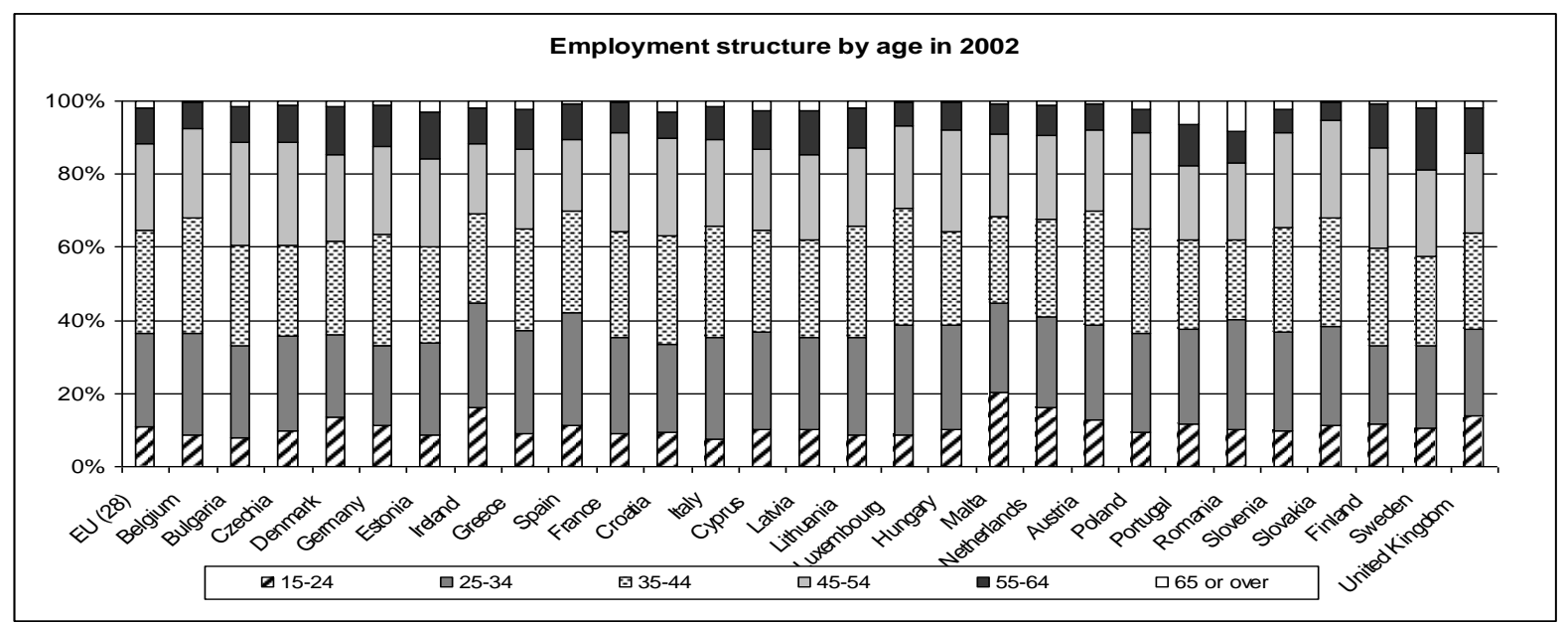

Figure 5. Employment structure by age in 2002 (Source: Own calculations based on data from the Eurostat database)

The largest percentage of employees is between the ages of 25 and 34 . The next two age categories also constitute a large proportion of the number of employees. For obvious reasons, the youngest and oldest people are the smallest percentage of the number of employees. Comparing these values, it can be seen that in many countries they are similar, although e.g. in Malta, the Netherlands, Austria or Ireland the percentage of the youngest employed people exceeds the percentage of the oldest employed. In order to show the changes that have taken place over the past over a dozen years, the employment structure in 2018 was examined (Fig. $6)$.



Figure 6. Employment structure by age in 2018 (Source: Own calculations based on data from the Eurostat database)

A change in structure is visible especially in extreme age ranges. There is a lower percentage of employed young people and an increased share of employed aged 55 or over; this observation is again a reflection of the changing age structure of the population.

\subsection{Spatial analysis of the employment rate}

The third part of empirical research included a spatial analysis of the employment rate. Global and local Moran's statistics were used in the considerations, which allow to identify spatial dependences. The analysis was carried out for three age ranges: for the youngest group (15$24)$, for the group of young and middle-aged people (25-54) and for people over 55 years of 
age. Significance level of 0.05 was adopted. Tab. 3 contains the values of global Moran's statistic, which indicate a tendency to cluster areas with a similar feature value, alternate distribution of values or lack of spatial patterns.

Table 3.

Values of Moran's I global statistic

\begin{tabular}{llllllll}
\hline \multirow{2}{*}{ Year } & \multicolumn{3}{c}{ Moran's $I$ statistic values } & \multirow{2}{*}{ Year } & \multicolumn{3}{c}{ Moran's $I$ statistics values } \\
\cline { 2 - 3 } & $15-24$ & $25-54$ & 55 or over & & $15-24$ & $25-54$ & 55 or over \\
\hline 2002 & 0.201 & 0.019 & 0.389 & 2011 & 0.191 & 0.185 & 0.386 \\
2003 & 0.202 & -0.040 & 0.442 & 2012 & 0.189 & 0.197 & 0.389 \\
2004 & 0.190 & -0.040 & 0.475 & 2013 & 0.192 & 0.195 & 0.381 \\
2005 & 0.189 & -0.010 & 0.452 & 2014 & 0.186 & 0.139 & 0.354 \\
2006 & 0.186 & 0.000 & 0.459 & 2015 & 0.184 & 0.090 & 0.337 \\
2007 & 0.185 & 0.000 & 0.417 & 2016 & 0.203 & 0.097 & 0.319 \\
2008 & 0.171 & -0.038 & 0.415 & 2017 & 0.161 & -0.032 & 0.275 \\
2009 & 0.154 & 0.054 & 0.323 & 2018 & 0.170 & -0.037 & 0.251 \\
2010 & 0.160 & 0.141 & 0.320 & & & & \\
\hline
\end{tabular}

Source: Own calculations

In the group of youngest people, throughout the entire period studied, we observe positive values of $I$ statistic - these values are in the range [0.160, 0.203]. This means weak positive spatial autocorrelation, i.e. a small tendency to cluster similar values. Confirmation of this dependency is also visible in Tab. 4, showing the existence of clusters of areas with similar levels of employment rate located mainly around Denmark (high values, above 40\%), in the neighbourhood of Lithuania (lower values, about 25\%), Ireland (above average), Romania (lower level, approx. 23\%) and Bulgaria (low level, approx. 20\%). Almost in the whole period there was also outlier - Austria, in which in the years 2003, 2005-2015 the employment level did not fall below $51 \%$, and which was surrounded by countries with significantly lower levels of the examined indicator.

In the next age group (25-54), the values of global Moran's statistic were positive or negative, but close to zero. In the years 2010-2014, the highest positive levels of the statistic occurred and in this period the largest tendencies to cluster similar values within neighbouring areas were visible. These clusters are most often made up of Sweden and neighbouring countries (employment rate above 80\%), and in 2012-2016 Bulgaria with Greece and their EU neighbours (level around 70\%). In this age group there were also outliers, which were most often Italy (employment rate most often below $70 \%$ - these values stood out compared to neighbours with higher levels of the phenomenon), as well as Slovenia (2005-2009, 2018), which recorded employment rate at the level of approx. $85 \%$ (the highest in the neighbourhood).

The last of the studied groups (people working over 55 years of age) throughout the entire studied period is characterized by significant positive values of global Moran's statistic covering the range [0.251, 0.459]. This means a tendency to cluster similar values within neighbouring locations. The strongest dependences are visible in the years 2003-2008. With the exception of 2002 there were no outliers (Romania, 64.2\% - much higher value than neighbours), while numerous clusters are visible, which are most often located around Sweden (on average, the values reach 65\%), Hungary (levels in the range [30\%, 40\%]) and Latvia (2006-2008, 2016, 2018) - close to $70 \%$. 
Table 4.

Outliers and clusters among the EU countries

\begin{tabular}{|c|c|c|c|c|c|c|}
\hline \multirow{3}{*}{ Year } & \multicolumn{6}{|c|}{ Countries } \\
\hline & \multicolumn{2}{|l|}{$15-24$} & \multicolumn{2}{|l|}{$25-54$} & \multicolumn{2}{|c|}{55 or over } \\
\hline & Outliers & Clusters & Outliers & Clusters & Outliers & Clusters \\
\hline 2002 & - & $\{\mathrm{DK}\}$ & $\{\mathrm{IT}\}$ & $\{\mathrm{DK}, \mathrm{SE}\}$ & $\{\mathrm{RO}\}$ & $\begin{array}{l}\{\mathrm{DK}, \mathrm{SE}\},\{\mathrm{HU}, \\
\mathrm{AT}, \mathrm{SI}, \mathrm{SK}\}\end{array}$ \\
\hline 2003 & $\{\mathrm{AT}\}$ & $\{\mathrm{DK}\}$ & $\{\mathrm{IT}\}$ & $\{\mathrm{SE}\}$ & - & $\begin{array}{l}\{\mathrm{DK}, \mathrm{SE}\},\{\mathrm{IT}, \mathrm{HU} \\
\mathrm{AT}, \mathrm{SI}, \mathrm{SK}\}\end{array}$ \\
\hline 2004 & & $\{\mathrm{DK}\},\{\mathrm{LT}\}$ & - & $\{\mathrm{SE}\}$ & - & $\begin{array}{l}\{\mathrm{DK}, \mathrm{SE}\},\{\mathrm{IT}, \mathrm{HU} \\
\mathrm{AT}, \mathrm{SI}, \mathrm{SK}\}\end{array}$ \\
\hline 2005 & $\{\mathrm{AT}\}$ & $\{\mathrm{DK}\},\{\mathrm{IE}\}$ & $\{\mathrm{IT}\},\{\mathrm{SI}\}$ & $\{\mathrm{SE}\}$ & - & $\begin{array}{l}\{\mathrm{DK}, \mathrm{SE}\},\{\mathrm{IT}, \mathrm{HU} \\
\mathrm{AT}, \mathrm{SI}, \mathrm{SK}\}\end{array}$ \\
\hline 2006 & $\{\mathrm{AT}\}$ & $\{\mathrm{DK}\},\{\mathrm{IE}\},\{\mathrm{RO}\}$ & $\{\mathrm{IT}\},\{\mathrm{SI}\}$ & $\{\mathrm{SE}\}$ & - & $\begin{array}{l}\{\mathrm{DK}, \mathrm{SE}\},\{\mathrm{IT}, \mathrm{HU}, \\
\mathrm{AT}, \mathrm{SI}, \mathrm{SK}\},\{\mathrm{EE}, \\
\mathrm{LV}\}\end{array}$ \\
\hline 2007 & $\{\mathrm{AT}\}$ & $\{\mathrm{DK}\},\{\mathrm{IE}\},\{\mathrm{RO}\}$ & $\{\mathrm{IT}\},\{\mathrm{SI}\}$ & $\{\mathrm{SE}\}$ & - & $\begin{array}{l}\{\mathrm{DK}, \mathrm{SE}\},\{\mathrm{HU}, \\
\mathrm{AT}, \mathrm{SK}\},\{\mathrm{EE}, \mathrm{LV}\}\end{array}$ \\
\hline 2008 & $\{\mathrm{AT}\}$ & $\{\mathrm{DK}\},\{\mathrm{IE}\},\{\mathrm{RO}\}$ & $\{\mathrm{IT}\},\{\mathrm{SI}\}$ & $\{\mathrm{DK}, \mathrm{SE}\}$ & - & $\begin{array}{l}\{\mathrm{DK}, \mathrm{SE}\},\{\mathrm{IT}, \mathrm{HU} \\
\mathrm{AT}, \mathrm{SK}\},\{\mathrm{EE}, \mathrm{LV}\}\end{array}$ \\
\hline 2009 & $\{\mathrm{AT}\}$ & $\{\mathrm{DK}, \mathrm{DE}\}$ & $\{\mathrm{IT}\},\{\mathrm{SI}\}$ & $\{\mathrm{DK}, \mathrm{DE}, \mathrm{SE}\}$ & - & $\begin{array}{l}\{\mathrm{DK}, \mathrm{SE}\},\{\mathrm{IT}, \mathrm{HU}, \\
\text { SI, SK }\}\end{array}$ \\
\hline 2010 & $\{\mathrm{AT}\}$ & $\{\mathrm{DK}, \mathrm{DE}\}$ & $\{\mathrm{IT}\}$ & $\{\mathrm{DK}, \mathrm{DE}, \mathrm{SE}\}$ & - & $\begin{array}{l}\{\mathrm{DK}, \mathrm{FI}, \mathrm{SE}\},\{\mathrm{IT}, \\
\mathrm{HU}, \mathrm{SI}, \mathrm{SK}\}\end{array}$ \\
\hline 2011 & $\{\mathrm{AT}\}$ & $\{\mathrm{DK}, \mathrm{DE}, \mathrm{NL}, \mathrm{SE}\}$ & $\{\mathrm{IT}\}$ & $\{\mathrm{DK}, \mathrm{DE}, \mathrm{SE}\}$ & - & $\begin{array}{l}\{\mathrm{DK}, \mathrm{FI}, \mathrm{SE}\},\{\mathrm{IT}, \\
\mathrm{HU}, \mathrm{SI}\}\end{array}$ \\
\hline 2012 & $\{\mathrm{AT}\}$ & $\{\mathrm{DK}, \mathrm{DE}, \mathrm{SE}\}$ & $\{\mathrm{IT}\}$ & $\begin{array}{l}\{\mathrm{BG}, \mathrm{GR}\},\{\mathrm{DE}, \\
\mathrm{SE}\}\end{array}$ & - & $\begin{array}{l}\{\mathrm{DK}, \mathrm{FI}, \mathrm{SE}\},\{\mathrm{HR}, \\
\mathrm{HU}, \mathrm{SI}\}\end{array}$ \\
\hline 2013 & $\{\mathrm{AT}\}$ & $\{\mathrm{DK}, \mathrm{DE}, \mathrm{SE}\}$ & $\{\mathrm{IT}\}$ & $\begin{array}{l}\{\mathrm{BG}, \mathrm{GR}\},\{\mathrm{DE}, \\
\mathrm{SE}\}\end{array}$ & - & $\begin{array}{l}\{\mathrm{DK}, \mathrm{FI}, \mathrm{SE}\},\{\mathrm{HR}, \\
\mathrm{HU}, \mathrm{SI}\}\end{array}$ \\
\hline 2014 & $\{\mathrm{AT}\}$ & $\{\mathrm{DK}, \mathrm{DE}, \mathrm{SE}\}$ & $\{\mathrm{IT}\}$ & $\begin{array}{l}\{\mathrm{BG}, \mathrm{GR}\}, \\
\{\mathrm{DE}\}\end{array}$ & - & $\begin{array}{l}\{\mathrm{DK}, \mathrm{FI}, \mathrm{SE}\},\{\mathrm{HR}, \\
\mathrm{HU}, \mathrm{SI}\}\end{array}$ \\
\hline 2015 & $\{\mathrm{AT}\}$ & $\{\mathrm{DK}, \mathrm{DE}, \mathrm{SE}\},\{\mathrm{BG}\}$ & $\{\mathrm{IT}\}$ & $\begin{array}{l}\{\mathrm{BG}, \mathrm{GR}\}, \\
\{\mathrm{DE}\}\end{array}$ & - & $\begin{array}{l}\{\mathrm{DK}, \mathrm{FI}, \mathrm{SE}\},\{\mathrm{HR}, \\
\mathrm{HU}, \mathrm{SI}\}\end{array}$ \\
\hline 2016 & - & $\{\mathrm{BG}, \mathrm{GR}\},\{\mathrm{DK}, \mathrm{SE}\}$ & $\{\mathrm{IT}\}$ & $\begin{array}{l}\{\mathrm{BG}, \mathrm{GR}\} \\
\{\mathrm{DE}\},\{\mathrm{CZ}\}\end{array}$ & - & $\begin{array}{l}\{\mathrm{DK}, \mathrm{SE}\},\{\mathrm{HR}, \\
\mathrm{SI}\},\{\mathrm{LV}\}\end{array}$ \\
\hline 2017 & - & $\{\mathrm{BG}\},\{\mathrm{DK}, \mathrm{DE}, \mathrm{SE}\}$ & $\{\mathrm{HR}\},\{\mathrm{IT}\}$ & - & - & $\{\mathrm{DK}, \mathrm{SE}\},\{\mathrm{HR}, \mathrm{SI}\}$ \\
\hline 2018 & - & $\begin{array}{l}\{\mathrm{BG}, \mathrm{GR}\},\{\mathrm{DK}, \mathrm{DE}, \\
\mathrm{SE}\}\end{array}$ & $\{\mathrm{IT}\},\{\mathrm{SI}\}$ & - & - & $\begin{array}{l}\{\mathrm{DK}, \mathrm{SE}\},\{\mathrm{HR}, \\
\mathrm{SI}\},\{\mathrm{LV}\}\end{array}$ \\
\hline
\end{tabular}

Source: Own study

\section{Conclusion}

The subject of the analysis was the assessment of the economic activity of the population, or rather the level, structure, dynamics and spatial dependence of employment, taking into account the division into age categories. In the majority of the European Union countries a slight upward trend is visible for the total number of employees, while in the category of the youngest there is a decrease or a slight increase, while among the oldest there is a significant average annual increase in the number of employees. The growing number of oldest people employed in 2018 is, among others, as a consequence of the aging of people who were a group of young or middle-aged people a dozen or so years ago.

Among the countries in which the employment rate in the category of the youngest people reached the highest values are primarily the Scandinavian countries, Germany and Austria, while in the countries of Southern Europe (Greece, Italy, Spain, Portugal) the employment rate fell. An upward trend is visible in the elderly category. There is also a noticeable change in the employment structure in almost all EU countries - this change consists in a decrease in the 
percentage of employed the youngest and young people, and an increase in the share of the number of employed older people. This is primarily the effect of demographic changes observed in European countries.

In addition, some spatial patterns are noted in the category of the youngest, and especially among the elderly. There are tendencies to cluster the value of the employment rate within neighbouring areas. These clusters are formed mainly around the Scandinavian countries, Western Europe and South-eastern Europe.

A question was also asked about the correlation of the employment rate in individual age categories with the measure of the quality of life and the level of economic development, which is GDP per capita (according to PPS). Different results were obtained - positive, negative, high or low absolute value of the Pearson's correlation coefficient, which can be explained in different ways depending on the country and age group. However, in the age category (55-64), with one exception - Portugal (0.43), a very strong positive linear dependence between the studied characteristics was obtained. This means that the increase in GDP per capita (according to PPS) is accompanied by an increase in the employment rate among older people.

The analysis of the employment rate showed above all changes in the age structure of people working over the period under review, confirming, inter alia, demographic changes taking place in Europe.

\section{References}

Anselin, L. (1995). Local Indicators of Spatial Association - LISA, Geographical Analysis, vol. 27(2), pp. 93-115.

Cliff, A.D. and Ord, J.K. (1973). Spatial Autocorrelation, London: Pion.

Eurostat (July 2019). Population structure and ageing. Available: https://ec.europa.eu/ eurostat/statistics-explained/index.php?title=Population_structure_and_ageing

Kopczewska, K. (2011). Ekonometria i statystyka przestrzenna z wykorzystaniem programu $R$ Cran, Warszawa: CeDeWu.

Jóźwiak, J. (2013). Demograficzne uwarunkowania rynku pracy w Polsce. Rynek pracy wobec zmian demograficznych w Polsce. Zeszyty Demograficzne. Warszawa, Poland.

Marciniak, S. (Ed.). (2013). Makro- i mikroekonomia. Podstawowe problemy wspótczesności. Warszawa: PWN.

Mastalerz-Kodzis, A., Miśkiewicz-Nawrocka, M., Pośpiech, E. and Zeug-Żebro, K. (2017). Czasowo-przestrzenna analiza charakterystyk spoleczno-ekonomicznych krajów Unii Europejskiej, Katowice: Wydawnictwo UE.

Overmars, K.P., de Koning, G.H.J. and Veldkamp, A. (2003). Spatial autocorrelation in multiscale land use models. Ecological Modelling, vol. 164, pp. 257-270.

Pietrzykowski, R. (2011). Wykorzystanie metod statystycznej analizy przestrzennej w badaniach ekonomicznych. Roczniki Ekonomiczne Kujawsko-Pomorskiej Szkoły Wyższej w Bydgoszczy, vol. 4, pp. 97-112.

Pośpiech, E. (2015) Analiza przestrzenna bezrobocia w Polsce, Studia Ekonomiczne. Zeszyty Naukowe Uniwersytetu Ekonomicznego w Katowicach, vol. 227, pp. 59-74.

Pośpiech, E. and Mastalerz-Kodzis, A. (2015). Autokorelacja przestrzenna wybranych charakterystyk społeczno-ekonomicznych. Metody ilościowe w badaniach ekonomicznych, vol. 16(4), pp. 85-94. 
Suchecki, B. (Ed.). (2010). Ekonometria przestrzenna. Metody i modele analizy danych przestrzennych, Warszawa, Poland: C.H. Beck.

Tobler, W. (1970). A Computer Model Simulating Urban Growth in Detroit Region, Economic Geography, vol. 46(2), pp. 234-240.

Zeug-Żebro, K. (2014). Analiza przestrzenna procesu starzenia się polskiego społeczeństwa, Studia i Prace Wydzialu Nauk Ekonomicznych i Zarzadzania, vol.36(2), pp. 441-456.

Database: Eurostat, Available: https://ec.europa.eu/eurostat/data/database 